\title{
Children, Public Libraries, and the Internet: \\ Is It Censorship or Good Service?
}

\author{
by Susan Colaric
}

$T$

he American Library Association (ALA), with its absolutist view of First Amendment rights, is doing a disservice to young library patrons. By insisting on open Internet access, regardless of age, the ALA is sending children into an information abyss that will most likely result in confusion, frustration, and poor research skills. ALA supports its position by saying that it is the parents' role to monitor their children's Internet use, but the problem of unaccompanied children in the library has been a concern of librarians for years.

While teaching critical thinking skills may be the best method to help children learn to find and review Web sites critically, there has been little research into whether children are capable of accomplishing this. In order to continue the tradition of protecting and assisting their younger patrons, librarians need to move the question of unfettered Internet access regardless of age from a legal issue to a moral one; is it the right thing to do?

The ALA has an absolutist view of the First Amendment and believes Internet access is included under the protections of the First Amendment, including unobstructed access by children. ${ }^{1}$ Article 5 of the Library Bill of Rights states that "A person's right to use a library should not be denied or abridged because of origin, age, background, or views." 2 The question of age was reinforced in the 1991 document, Free Access to Libraries for Minors: An Interpretation of the Library Bill of Rights: "Library policies and procedures which effectively deny minors equal access to all library resources available to other users violate the Library Bill of Rights." ${ }^{3}$ In 1996 the ALA made clear that the Library Bill of Rights also pertained to electronic access to information: "Electronic information, services, and networks provided directly or indirectly by the library should be equally, readily and equitably accessible to all library users." 4

While the principles stated above are supported by most librarians there is also considerable disagreement. ${ }^{5}$ Most of the concern stems from the unregulated nature of the Internet; anyone can post sites that are then available to anyone with World Wide Web (Web) access. While pornography is usually the issue that raises peoples' objections the Web is also replete with incomplete information, pranks, contradictions, out-of-date information, improperly translated data, unauthorized revisions, factual errors, biased information, and scholarly misconduct. ${ }^{6}$ Ann Symons, former ALA President, wrote in the April 1997 edition of School Library Journal, "The amount of useless content on the Web boggles the imagination. If you've spent even one 
day surfing the Net, it's obvious that you would never select more than one percent of what's on the Web for your print collection .... As librarians who select and organize information, we know that evaluating information can be difficult." 7

My contention is that if this task is difficult for trained information professionals then for children this task is not only difficult, it may be impossible. Children may not have the cognitive ability to do an evaluation of credibility. And when we have asked children and parents to trust that the library is a source for good information we have a problem when we present something that may not be reliable. We are, in fact, doing our young patrons a disservice by not providing them with a reviewed/evaluated version of the Web.

\section{Children's Use of the Library}

The library community has always welcomed children and developed specialized programming to introduce them to books and research in the library. Librarians have worked hard to develop the trust of children and their parents. This trust has taken two forms: the library is a safe place for children to explore and the library provides accurate information for its patrons.

The quiet, scholarly atmosphere of most libraries tends to give parents a sense of security. While this is essential to providing an atmosphere of relaxation and invitation it has resulted in some unexpected consequences. In the late 1980s the issue of "latchkey" children in the library surfaced in the professional literature. Numerous articles mentioned children as young as six using the library after school because they lacked supervision at home. ${ }^{8}$ While some of these children are there by choice, others are instructed by parents and guardians to go to the library until the parent picks them up after work.

A survey among large public library systems in 1989 found that $98.6 \%$ of librarians felt that parents perceived the library as a "safe" place for their children. ${ }^{9}$ Many librarians have, in fact, instituted after-school programs that support this idea of a safe haven for children. ${ }^{10}$ Diana Young, in advising libraries on developing "latchkey children" policies, states that the highest priority when stating the objectives of the policy should be "to communicate the library's concern for child safety and welfare to the community." 11

The other area of trust that is vested in the library is the expectation of accurate information. Professional librarians have been trained in and work with carefully designed selection development policies that assure that the money spent in the library is for factual and credible sources. "Our student and adult patrons have come to expect, when they walk into a library, to find accurate, balanced information because someone professionally trained has selected the materials there for currency, accuracy, and relevancy."12

The Internet threatens both of these areas of trust. By allowing children to search the Internet without mediation they are subject to information that is potentially very harmful as well as a great deal of information that is inaccurate. The fact that many children use the library unaccompanied by parents exacerbates this situation.

\section{The Nature of Information on the World Wide Web}

Traditionally libraries acquired the resources on their shelves through publishers who felt an obligation to review and edit books to ensure accuracy and reliability. The librarian then offered a second "review" of the material before it was purchased and made available in the public library. This second review included not only the accuracy and currency of the material but a determination as to the contribution the resource would make to the entire collection. Librarians also frequently review the items currently on the shelves and purge outdated, discredited, or damaged materials. This process 
is the antithesis of the World Wide Web.

The freedom to post information on the Web is unlimited and there is generally no review process. Anyone can post a professional-looking site that contains biased, incorrect, or dangerous information. Stephen Kerr, professor at the College of Education at the University of Washington describes it as "information by anyone, for anyone. There's racist stuff, bigoted, hate-group stuff, filled with paranoia; bomb recipes; how to engage in various kinds of crimes, elec-

Evaluation of Web sites is a recognized concern in the library community. ... If trained information professionals need ... guidance, can we really expect that children will be able to handle the task independently? tronic and otherwise; scams and swindles. It's all there. It's all available." 13 While this can be seen as the democratic ideal in that minority and unpopular voices now have a venue for disseminating their opinions, it can also be confusing and misleading. And once a site is "posted" it rarely comes down, even when outdated. In order to find reliable information each Web site needs to be examined with a critical eye.

Evaluation of Web sites is a recognized concern in the library community. In an article written to assist librarians with this task, Nancy Everhart offers nine categories for review with a total of 40 checkpoints with which to evaluate Web sites; of these 17 deal with evaluating credibility. ${ }^{14}$ Carolyn Caywood, writing on the same subject, divides the task into three categories (access, design, and content) with 12 questions concerning the credibility of the content. ${ }^{15}$ Nicole Auer, a librarian at Virginia Polytechnic Institute and State University, maintains an on-line bibliography concerning this subject. She currently has listed over 60 sources dealing with how to evaluate Web sites. ${ }^{16}$ If trained information professionals need this type of guidance, can we really expect that children will be able to handle the task independently?

\section{Children's Information Seeking Skills}

Little research has been done to shed light on the way children find and use information in their lives and even less has been done on the developmental aspects that affect their abilities as they mature. In a concept paper written for the National Commission on Libraries and Information Science concerning the role of the school library media program and how it needs to change in teaching information-finding/utilization skills to children and young adults, Mancall, Aaron, and Walker state: "Individual students' fundamental mental processes, including their developmental aspects are often neglected, and the implications for both teachers and students of helping the young develop the ability to think about how they are using the information to solve problems are frequently ignored."17 Although it is not possible to label children as being developmentally ready when, for instance, they turn 10, most developmental theorists agree that there are basic similarities in children's behavior at different ages or points in their development. ${ }^{18}$

Carol Kuhlthau conducted two studies in the early 1980s to observe elementary and high school students as they used their school libraries to complete classroom assignments. ${ }^{19}$ She found that their information needs concurred with the developmental stages described by developmental psychologists, including Piaget, Erikson, Kohlberg, and Bruner. As children mature, their information-seeking skills improve and their ability to compare resources becomes evident. This process occurs as a result of maturation and learning. While Kuhlthau's studies provided an opening for further research into the cognitive stages of information retrieval, very little has been done. In the few studies that have followed on children's information seeking (print and electronic formats), four factors have been examined: selection of 
search terms, constructing effective search arguments, time spent searching, and credibility of information found on the Web. These factors correspond to the stages of the search process.

Selection of search terms can be a difficult process and the results from studies on children's selection of search terms are mixed. Gary Marchionini in researching elementary school children's use of a full-text electronic encyclopedia found that most students were able to identify key facts successfully and select search terms, although younger searchers (9 years old) used sentences and phrases rather than individual keywords. ${ }^{20}$ Spavold's research with 9- to 11-year olds working with a database of census material supported this finding. ${ }^{21}$ However, Moore and St. George reported that the selection of search terms may be beyond the ability of many 10- to 12-year olds; although all students were able to identify what they thought was an appropriate term, more than one third of the words the children selected were inappropriate as judged by an adult rater. ${ }^{22}$ This supported Moore's earlier research where the children had difficulty generating alternative terms and $70 \%$ of those generated would not access any points in the Dewey Decimal Classification System. ${ }^{23}$

The next step in the search process is to integrate the search terms into a successful search strategy. Here, the research is overwhelming negative as to children's abilities. Schacter, Chung, and Dorr found that children rarely employ systematic search strategies and spend little to no time planning their searches. $^{24}$ This supported earlier research that showed that children between the ages of 9 and 12 have difficulty constructing effective search strategies. ${ }^{25}$ In fact, browsing may be a more developmentally appropriate strategy at this age, as it requires less cognitive load than query formulation. ${ }^{26}$

Assuming that the child has been successful up to this point of identifying appropriate search terms and constructing a search strategy, with the Web the hard part is still to come. Now the child must choose the appropriate search engine and interpret the search strategy according to the syntax supported by that engine. Most likely, at this point, hundreds of references will be returned. Will the child spend the necessary time to get this far and start sorting through the

Children will need to learn to analyze and challenge the authority of documents, not just assume the document is credible; yet we don't have any research that shows that children are able to do this. returns? Possibly not. Borgman, Hirsh, Walter, and Gallagher conducted a study of children's use of a library catalog and found that children aged 9 to 12 would only spend approximately three-and-a-half minutes on a search before abandoning it; and this was conducted on a system where there were, in fact, several "successes" for the children to find. ${ }^{27}$

Most alarming when it comes to letting children loose on the Web, however, is the credibility of the sites. Children will need to learn to analyze and challenge the authority of documents, not just assume the document is credible; yet we don't have any research that shows that children are able to do this. Schacter, Chung, and Dorr at the Graduate School of Education and Information Studies at the University of California, Los Angeles, conducted a study to examine children's performance and process analyses for finding information on the Web. ${ }^{28}$ The results indicated that children had difficulty finding information on the Web and that they did better with ill-structured problems than they did with well-structured problems. Very disturbing, however, was the fact that children assumed what they found while searching the Web was accurate. "Children do not seem to be cognizant that false, inaccurate information is posted and that the information they find needs to be challenged and questioned. This finding should be 
taken with caution as only one item asked children how true they believed the information they bookmarked was, yet, at the same time, this result sets a precedence that children need to be taught about the manipulative powers of media." ${ }^{29}$ Another disturbing finding from the same study was that few students bookmarked counter arguments to the solutions they found and even less pursued multiple solutions; they simply went with the first ones that "looked good."

My first reaction when reviewing this literature is that more information is needed on children's information-seeking behaviors and attitudes. The few studies presented here are not a clear enough picture to develop an understanding of their cognitive processes or abilities at various stages of development. Another concern is that these results may have been found because the abilities that the students need have never been taught to them. Perhaps the correct course of action is the development of a curriculum for finding and evaluating information. In fact, this step has already been offered as a solution by the introduction of the Information Literacy Standards for Student Learning. ${ }^{30}$ Yet the pursuit of clear research will take a number of years before we see valid results. I believe we should act on the information that we have and move to protect children as they use public libraries.

While the ALA is to be commended for its support of adults having unfiltered access to the Internet, children are not "small adults." As librarians we already provide age-appropriate seating, bookshelves, and wall decorations that support this idea. Our professional observations and the research have shown that children access and view information differently from adults. Why would we then ignore this information? The availability of the Internet in the library needs to be reviewed and its purpose made clear.

A very simple method can be used to protect children while still protecting adult First Amendment rights. If a terminal is available in the children's room of the library, it should be set up to make it most useful to those patrons likely to sit down on the presumably small chair and do research. Pictures, large type, and browsing rather than search strategies are what is appropriate for this audience. The children's librarian should treat the Internet as an additional resource that he or she locates, evaluates, and then decides to bring into the library and make accessible to his or her patrons. He or she can do this by bookmarking sites that are credible, entertaining, and educational and only allowing access to reviewed sites.

When an Internet terminal is located in the "adult section" of the library, why not locate it out of sight from the children's area? I am not suggesting that librarians become policeman and ask children to leave the adult area, but by making the computers less obvious to children they are more likely to use the ones developed for them, leaving others for adult searchers. As children grow older and make the natural transition into other parts of the library, they may be better prepared for unfiltered access. This is the policy that many libraries have adopted when classifying adult and children's books - why not for the Internet?

If we librarians, as a profession, value and choose to protect young patrons from "bad" information, then this is the least we can do until more is known about children's use of the Internet. Or, if we believe so strongly in the unfiltered benefits of the Internet, why don't we mimic its structure? We can just take all the books off the shelves, mix fiction, non-fiction, videos, children's books, encyclopedias, and comic books in great big heaps on the floor and see how well a child can find what he or she needs. 


\section{References}

1 American Library Association, Library Bill of Rights (Chicago: ALA, 1996); American Library Association, Free Access to Libraries for Minors: An Interpretation of the Library Bill of Rights (Chicago: ALA, 1991); American Library Association, Access to Electronic Information, Services, and Networks: An Interpretation of the Library Bill of Rights (Chicago: ALA, 1996); American Library Association, Questions and Answers: Access to Electronic Information, Services, and Networks: An Interpretation of the Library Bill of Rights (Chicago: ALA, 1997); American Library Association, Resolution on the Use of Filtering Software in Libraries (Chicago: ALA, 1997).

2 American Library Association, Library Bill of Rights.

3 American Library Association, Free Access to Libraries for Minors.

4 American Library Association, Access to Electronic Information, Services, and Networks.

5 Beverly Goldberg, "14,410 Letters Protest ALA Filtering Policy," American Libraries 29 (Aug. 1998): 16-17.

${ }^{6}$ Mary Ann Fitzgerald, "Misinformation on the Internet: Applying Evaluation Skills to Online Information," Emergency Librarian 24 (Jan./Feb. 1997): 9-14; Todd Oppenheimer, "The Computer delusion," The Atlantic Monthly 280 (July 1997): 45-62.

7 Ann K. Symons, "Sizing Up Web Sites: How to Judge What You Find on the Web," School Library Journal 43 (Apr. 1997): 22.

8 Frances S. Dowd, "Serving Latchkey Children: Recommendations from Librarians," Public Libraries 28 (Mar./Apr.): 101-6; Diana Young, "Latchkey Children in the Public Library," Public Libraries 27 (Winter 1988): 196-98; Holly G. Willett, "The Changing Demographics of Children's Services," Journal of Youth Services in Libraries 2 (Fall 1988): 40-50; Frances S. Dowd, "The Public Library \& the Latchkey Problem: A Survey," School Library Journal 35 (July 1989): 19-24; Actor Cordell, "Unattended Children Left at Libraries," The Atlanta Constitution (Dec. 5, 1991): 5, 7; Danielle A. Fouquette, "Libraries' Young Patrons Are Often Latchkey Children: Working Parents View Facilities as a Safe After-School Refuge," Los Angeles Times (Mar. 22, 1992): 3; Rosanne Cerny, "An After School Solution," School Library Journal 40 (Nov. 1994): 49; E. Jensen, "Unruly Youth Cause Problems for Librarians," The Arizona Republic/The Phoenix Gazette (Aug. 8, 1994): 1; Frances S. Dowd, "Public Library Programs for Latchkey Children: A Status Report," Public Libraries 34 (Sept./Oct. 1995): 291-95; Patricia Davis, "Where the Students Are Stars: Library Center Tutors Young Immigrants," The Washington Post (Mar. 12, 1998): V1.

9 Dowd, "The Public Library \& the Latchkey Problem."

${ }^{10}$ Dowd, "Serving Latchkey Children"; Young, "Latchkey Children in the Public Library"; Willett, "The Changing Demographics of Children's Services"; Cerny, "An After School Solution"; Dowd, "Public Library Programs for Latchkey Children"; Davis, "Where the Students Are Stars."

11 Young, "Latchkey Children in the Public Library," 197.

12 Mark E. Williams, "Evaluating Web Sites: Four Criteria," CSLA Journal 21 (Spring 1998): 16.

13 Oppenheimer, "The Computer Delusion," 61.

14 Nancy Everhart, "Web Page Evaluation," Emergency Librarian 25 (May/ June 1998): 22.

15 Carolyn Caywood, "Selection Criteria for World Wide Web Resources," Public Libraries 35 (May/June 1996): 169.

${ }^{16}$ Nicole J. Auer, "Bibliography on Evaluating Web Information," <http:// www.lib.vt.edu/research/evaluate/evalbiblio.html\#top> Accessed 22 Oct. 2002.

17 Jacqueline C. Mancall, S.L. Aaron, and S.A. Walker, "Educating Stu- 
dents to Think: The Role of the School Library Media Program," School Library Media Quarterly 15 (Fall 1986): 20.

18 Dorothy G. Singer, and Tracey A. Revenson, A Piaget Primer: How a Child Thinks. Rev. ed. (Madison, CT: International Universities Press, 1997).

${ }^{19}$ Carol Kuhlthau, "Meeting the Information Needs of Children and Young Adults: Basing Library Media Programs on Developmental States," Journal of Youth Services in Libraries 2 (Fall 1988): 51-57.

20 Gary Marchionini, "Information-Seeking Strategies of Novices Using a Full-Text Electronic Encyclopedia," Journal of the American Society of Information Science 40 (Jan. 1989): 54-66.

21 Janet Spavold, "The Child as Naïve User: A Study of Database Use with Young Children," International Journal of Man-Machine Studies 32 (June 1990): 603-25.

22 Penelope A. Moore, and Alison St. George, "Children as Information Seekers: The Cognitive Demands of Books and Library Systems," School Library Media Quarterly 19 (Spring 1991): 161-68.

${ }^{23}$ Penelope A. Moore, "Children's Information Seeking: Judging Books by Their Covers," School Library Review 8 (1988): 5.

${ }^{24}$ John Schacter, Gregory K.W.K. Chung, and Aimee Dorr, “Children's Internet Searching on Complex Problems: Performance and Process Analyses," Journal of the American Society for Information Science 49 (July 1998): 840-49.

25 Marchionini, "Information Seeking Strategies of Novices Using a FullText Electronic Encyclopedia"; Spavold, "The Child as Naïve User"; Gary Marchionini, Information Seeking in Electronic Environments (Cambridge: Cambridge University Press, 1995); Penny Moore, "Information Problem Solving: A Wider View of Library Skills," Contemporary Educational Psychology 20 (Jan. 1995): 1-31.

${ }^{26}$ Marchionini, Information Seeking in Electronic Environments; Schacter, Chung, and Dorr, "Children's Internet Searching on Complex Problems."

27 Christine L. Borgman, Sandra G. Hirsh, Virginia A. Walter, and Andrea L. Gallagher, "Children's Searching Behavior on Browsing and Keyword Online Catalogs: The Science Library Catalog Project," Journal of the American Society for Information Science 46 (Oct. 1995): 663-84.

${ }^{28}$ Schacter, Chung, and Dorr, "Children's Internet Searching on Complex problems."

${ }^{29}$ Ibid., 848.

30 American Association of School Librarians and Association for Educational Communications and Technology, Information Literacy Standards for Student Learning (Chicago: ALA, 1998). 